\title{
A Critical Assessment of Contemporary Pharmacy Curriculum: Views and Experiences of Foreign Trained Pharmacists
}

\author{
Mohammed Elijah NA ${ }^{1}$, Adigwe Obi Peter ${ }^{2}$, and Onavbavba Godspower ${ }^{2 *}$
}

${ }^{1}$ Pharmacists Council of Nigeria, Idu, Abuja, Nigeria

${ }^{2}$ National Institute for Pharmaceutical Research and Development, Idu Abuja, Nigeria

DOI: $10.36347 /$ sajp.2020.v09i07.003

| Received: 19.06.2020 | Accepted: 26.06.2020 | Published: 08.07.2020

*Corresponding author: Onavbavba Godspower

Abstract

Original Research Article

Students who are offered admission into higher institutions have varying educational and socio-economic backgrounds and indeed, some of these students have limited academic abilities. Universities therefore have to be creative in the manner that they facilitate learning; support students' needs; review curriculum to fit socioeconomic priorities; and respond to new realities and opportunities for this group of stakeholders. This study aimed at assessing the views and experiences of foreign trained pharmacy graduates on pharmacy curriculum's fitness of purpose for contemporary pharmacy practice. Student's level of satisfaction with how they are assessed can give invaluable insight into the responsiveness of the curriculum to issues and challenges associated with contextual practice. In this study, wellstructured questionnaires were administered to foreign trained pharmacy graduates with the ethical precepts of anonymity and confidentiality maintained. Likert type scale of 1 to 5 was adopted, and data were analyzed using Statistical Package for Social Sciences software version 21. a total of 97 questionnaires were administered, response rate was $85.57 \%$, respondents were made up of 39 males and 44 females, majority of them $(66.3 \%)$ were between the age of 21 to 25 , more than a third $(37 \%)$ of them studied in Asia, less than one-tenth (7.2\%) of them had MPharm degree, the factor loading for all the items were between 0.601 to 0.869 and the Cronbach alpha value for the questionnaire was 0.961 . The study revealed that the respondents were satisfied with the method of assessment that was used for them in pharmacy school but would have preferred assessment and evaluation based on critical thinking feedback.

Keywords: Pharmacy, Curriculum, Critical thinking, Problem-based learning.

Copyright @ 2020: This is an open-access article distributed under the terms of the Creative Commons Attribution license which permits unrestricted use, distribution, and reproduction in any medium for non-commercial use (NonCommercial, or CC-BY-NC) provided the original author and source are credited.

\section{INTRODUCTION}

Candidates admitted to study professional courses in higher institutions usually come from diverse sociocultural and socio-economic backgrounds. As a result of this, significant variations exist in the relevant skills and abilities prerequisite for subsequent training and attainment of academic qualifications. Institutes of learning have to therefore be resourceful and innovative in developing strategies for selecting, training and preparing students for a pharmaceutical practice that is not only impactful, but also, ideal for addressing healthcare challenges that exist in various relevant settings $[1,2]$. The traditional teaching curriculum tends to burden students by placing too much emphasis on memorization and information overload. Consequently, students tend to acquire a substantial volume of knowledge which they cannot apply in practice setting when required [3]. Practicing as a pharmacist requires that the individual must have the ability to think analytically, clearly, and critically, as well as interpret scientific evidence relevant to various contextual issues. For the practice, curriculum design and teaching practices are therefore critical factors that influence the development of scientific thinking and lifelong professional socialization [4-6].

Enabling this paradigm shift requires significant input from students, and several schools of pharmacy have modified their curriculum to accommodate students' views and experiences [7-10]. There is evidence that this innovative approach has led to increased students' satisfaction, which in turn, influenced positive learning outcomes. High levels of student satisfaction have been reported when interdisciplinary approach was used to teach some pharmacy topics [11]. Aside from promoting some topics as an integrative subject, some studies have demonstrated the need for implementation of activeteaching modalities such as team-based learning, 
problem-based learning, case-study exercise, and technology-based teaching into pharmacy curriculum $[8,12,13]$. The addition of team-based learning, problem-based learning, and case-study exercise to pharmacy curriculum has resulted in more positive perception of students about some courses that they considered difficult [14]. The implementation of technology-based teaching has also led to increase in students' engagement [15]. The evidence therefore suggests that innovative approaches in pharmacy curriculum review enables professionals with the relevant expertise to deal with issues contextual to their practice settings, for instance, Medicines' Security [16] in developing countries.

One of such innovations in Healthcare Sciences' curriculum reform is the introduction of problem-based learning methodology which emphasizes outcomes that learners are required to achieve, throughout the learning process. A study by Insull and Blyth [17] on medical students in New Zealand which aimed at determining their confidence levels for different subjects, provided some insight as to how their basic science knowledge could influence the safety of their medical practice. The findings from the study indicated that students were most confident in their behavioural science knowledge and least confident in their knowledge of pharmacology. This consequently provided more information about where reforms were most critical [17]. Historically, the Problem-based learning methodology was developed as an innovative teaching tool that could stimulate a bottom-up approach to enable the emergence of appropriate solutions for contextual issues. The learning process involves the simulation of real-life scenarios which evidence has shown that students can better relate with. The approach has also been shown to improve communication skills as well as provide opportunity for better team work. Findings further indicate that the adoption of the approach stimulates independent working, since students have been known to acquire knowledge and find information through research, without the presence of a teacher. Other attributes associated with the approach include activation of prior knowledge; critical thinking skills; discussion and brain-storming; as well as problem-solving and collaborative learning [17-20].

Although the problem-based learning methodology is now widely used in professional pedagogy, stakeholder assessment in the form of students' satisfaction remains a rate limiting step in its application in curriculum reform. Curricula ought to be regularly reviewed to enable a robust response to various factors, including professional changes, socioeconomic needs and proclivities of the target demography [2]. Assessing the level of satisfaction with pharmacy curriculum has been identified as a veritable tool for identifying relevant strengths and weaknesses [21]. In many developing countries, there is a need to increasingly advocate for such an evidence-based approach in reforms associated with professional pedagogy. So far, there is little evidence in the extant literature that a robust and comprehensive exploration of stakeholders' views and experience has been undertaken in various relevant areas, or that their level of satisfaction with existing curricula have been assessed. This study therefore aimed at assessing the views of foreign trained pharmacy graduates on pharmacy curriculum with the focus of determining better ways of training pharmacists as well as determining the level of satisfaction with the curriculum that underpinned their professional training.

\section{METHODS}

\section{Data Collection Procedure}

Questionnaires were administered to foreign pharmacy graduates who were undergoing a certification programme aimed at ensuring that foreign trained pharmacists are fit to practice in Nigeria. Appropriate instructions on how to fill the questionnaires were given before distribution. Convenience sampling strategy was employed in data collection [22]. A total of 97 questionnaires were distributed, and consent was obtained from respondents before the questionnaires were administered. Confidentially was maintained in the data collection process. Data collected include demographic details, teaching assessment, learning assessment, and method of assessment/evaluation. A Likert scale of 1 to 5 was employed in data collection.

\section{Data Analysis}

Data were coded and appropriately entered into Statistical Package for Social Sciences (SPSS) software version 21 for data analysis [23]. Descriptive and inferential statistics were applied to the data after relevant collation. Chi square test was also carried out and the level of significance for all statistical tests were set at $P \leq 0.05$.

\section{RESULTS \\ Socio Demography}

Response rate was $85.57 \%$, the respondents were made up of 39 males and 44 females, majority of the respondents $(66.3 \%)$ were between the age of 21 and 25 , more than a third $(37 \%)$ of them studied in Asia, less than one-tenth (7.2\%) of them had MPharm degree. Further details on socio demographic characteristics are presented in table 1 below. 
Table-1: Socio Demographic Characteristics of the Respondents

\begin{tabular}{|l|l|}
\hline $\begin{array}{l}\text { Variables } \\
\text { n=83 }\end{array}$ & N (\%) \\
\hline $\begin{array}{l}\text { Gender } \\
\text { Male } \\
\text { Female }\end{array}$ & $39(47.0)$ \\
\hline Age & $44(53.0)$ \\
\hline$<20$ & $1(1.2)$ \\
\hline $21-25$ & $55(66.3)$ \\
\hline $26-30$ & $23(27.7)$ \\
\hline$>30$ & $4(4.8)$ \\
\hline Continent of Study & \\
\hline Africa & $18(21.7)$ \\
\hline Asia & $31(37.3)$ \\
\hline Europe & $10(12.0)$ \\
\hline South America & $1(1.2)$ \\
\hline Missing data & $23(27.7)$ \\
\hline Qualification & \\
\hline BPharm & $61(73.5)$ \\
\hline PharmD & $13(15.7)$ \\
\hline MPharm & $6(7.2)$ \\
\hline Others & $2(2.4)$ \\
\hline Missing data & $1(1.2)$ \\
\hline
\end{tabular}

\section{Teaching and Learning}

Questions were asked to determine the respondents' rating on the teaching and learning processes of their various curriculum. Details of the responses by the respondents are presented in figure 1.1 below.

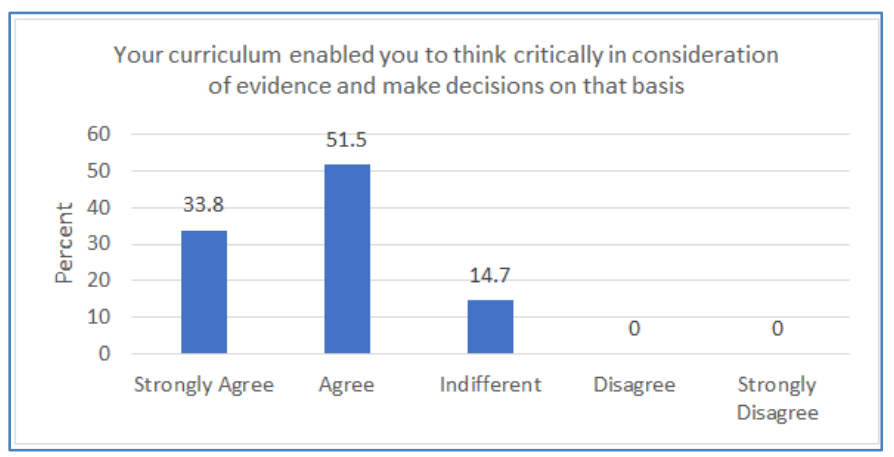

Fig-1.1: Critical thinking skills

Figure 1.2 provides results associated with the respondents' ability to assess scientific evidence and from the responses given, they were encouraged to think critically in consideration of scientific evidence. Further details are presented in figure 1.2 below.

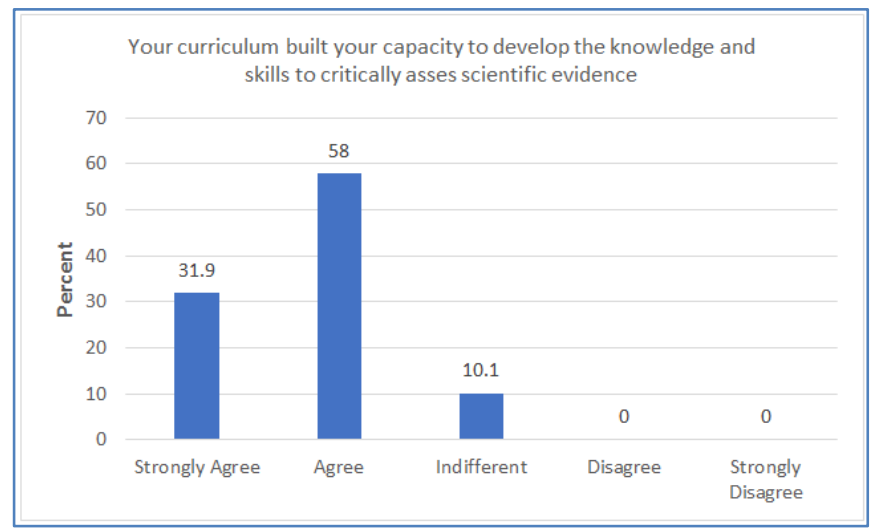

Fig-1.2: Capacity to Critically Assess Scientific Evidence 
Research and scholarly activities are important in pharmacy practice due to the fact that pharmacists are required to update their knowledge regularly so as to keep pace with modern evidence-based practice. Majority of the respondents indicated that they were encouraged to participate in research and scholarly activities in order to generate new knowledge in pharmacy practice. Details are presented in figure 1.3 below.

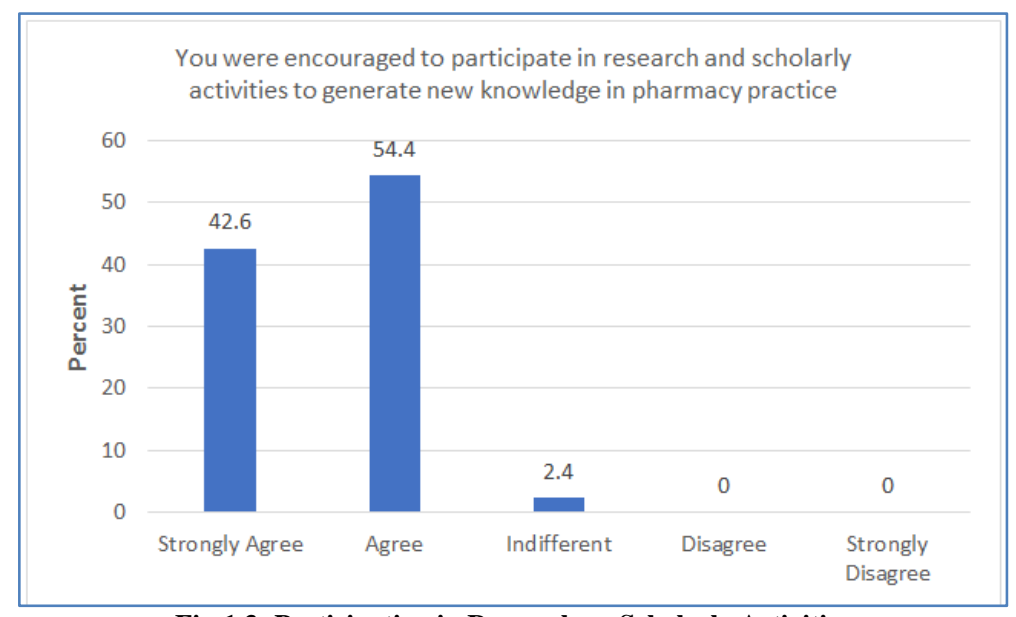

Fig-1.3: Participation in Research on Scholarly Activities

\section{Method of Assessment, Grading and Evaluation}

Systematic programmes are instituted to assess students' knowledge, attitude, and skills resulting from academic and curricular programmes. Different schools have varying methods of assessing their students. The respondents that were assessed using critical thinking skills were $3 \%$ while others were assessed using conventional means, including examinations and tests.
Close to a third of the respondents (29\%) where graded using the Cumulative Grade Point Average (CGPA), more than one-tenth $(13 \%)$ of them were graded by percentage while others were graded with pass and fail. A small proportion of the respondents (3\%) were evaluated annually (sessional) while majority of them $(97 \%)$ were evaluated every semester. Further details about assessment are presented in table 2 below.

Table-2: Frequency Distribution for Assessment

\begin{tabular}{|l|l|l|l|l|}
\hline SN & \multicolumn{1}{|c|}{ Item questions } & N & \multicolumn{2}{c|}{ Response N (\%) } \\
\hline & \multicolumn{1}{|c|}{} & \multicolumn{1}{c|}{ Yes } & No \\
\hline 1 & Was this method of grading/assessment satisfactory to you & 39 & $37(94.9)$ & $2(5.1)$ \\
\hline 2 & $\begin{array}{l}\text { Would you have preferred an assessment /evaluation } \\
\text { based on critical thinking feedback? }\end{array}$ & 37 & $26(70.3)$ & $11(29.7)$ \\
\hline 3 & $\begin{array}{l}\text { Would you have preferred a more engaging process } \\
\text { instead of providing categorical answers? }\end{array}$ & 33 & $27(81.8)$ & $6(18.2)$ \\
\hline
\end{tabular}

Various suggestions were however made by the respondents on better ways they consider for assessment and grading, many of the responses received suggested a preference for assessment based on critical thinking skills. Details presented in table 3 below are indicative of data collected in this area.

Table-3: Suggestion on Different Ways the Respondents Considered a Better Method for Assessment and Grading

\begin{tabular}{|l|l|}
\hline Respondent & Response \\
\hline Questionnaire 30 & Making students to go extra miles while reading and also been able to answer indirect questions \\
\hline Questionnaire 32 & Oral interview (viva) \\
\hline Questionnaire 41 & Grading base on understanding \\
\hline Questionnaire 33 & Assessment on critical thinking \\
\hline Questionnaire 62 & Assessment of practical skills and strategy \\
\hline Questionnaire 69 & 5 point grading system \\
\hline Questionnaire 73 & All areas of the courses should be touched rather than selecting some few topics for exam \\
\hline Questionnaire 75 & Practical and basic knowledge \\
\hline Questionnaire 76 & There should demonstration of more practical approach to learning \\
\hline
\end{tabular}




\section{Cross-Tabulation of Responses with Socio-}

Demography

The results from cross-tabulation indicated that some of the responses of the respondents were influenced by their socio demographic characteristics, chi square was considered to be significant at $P \leq 0.05$. The details of the cross-tabulation results for teaching and learning with continent of study are presented in table 4 below.

Table-4: Cross-Tabulation of Teaching and Learning with Continent of Study

\begin{tabular}{|c|c|c|c|c|c|c|c|c|c|}
\hline SN & Item Question & $\begin{array}{l}\text { Response } \\
(\%)\end{array}$ & $\begin{array}{l}\text { Africa } \\
(\%)\end{array}$ & $\begin{array}{l}\text { Asia } \\
(\%)\end{array}$ & $\begin{array}{l}\text { Europe } \\
(\%)\end{array}$ & $\begin{array}{l}\text { South } \\
\text { America } \\
(\%)\end{array}$ & $X^{2}$ & DF & $P$-value \\
\hline \multirow[t]{3}{*}{1} & \multirow{3}{*}{$\begin{array}{l}\text { Your curriculum enabled you to } \\
\text { think critically in consideration } \\
\text { of evidence and to make } \\
\text { decisions on that basis }\end{array}$} & $\begin{array}{l}\text { Strongly } \\
\text { Agree }\end{array}$ & 22.2 & 61.1 & 11.1 & 5.6 & 26.544 & 6 & 0.0001 \\
\hline & & Agree & 35.7 & 57.1 & 7.1 & - & & & \\
\hline & & Indifferent & 14.3 & - & 85.7 & - & & & \\
\hline \multirow[t]{3}{*}{2} & \multirow{3}{*}{$\begin{array}{l}\text { Your curriculum built your } \\
\text { capacity to develop the } \\
\text { knowledge and skills to critically } \\
\text { assess scientific evidence }\end{array}$} & $\begin{array}{l}\text { Strongly } \\
\text { Agree }\end{array}$ & 16.7 & 66.7 & 11.1 & 5.6 & 18.194 & 6 & 0.006 \\
\hline & & Agree & 35.5 & 51.6 & 12.9 & - & & & \\
\hline & & Indifferent & 20.0 & - & 80.0 & - & & & \\
\hline \multirow[t]{3}{*}{3} & \multirow{3}{*}{$\begin{array}{l}\text { You were encouraged to } \\
\text { participate in research and } \\
\text { scholarly activities to generate } \\
\text { new knowledge in pharmacy }\end{array}$} & $\begin{array}{l}\text { Strongly } \\
\text { Agree }\end{array}$ & 33.3 & 50.0 & 12.5 & 4.2 & 10.674 & 6 & 0.099 \\
\hline & & Agree & 25.9 & 55.6 & 18.5 & - & & & \\
\hline & & Indifferent & - & - & 100 & - & & & \\
\hline
\end{tabular}

Results were also collected for the crosstabulation of the items under teaching and learning with qualification. Only one of the items was statistically significant as other items had a $P$-value higher than 0.05 . Further details are presented in table 5 below.

Table-5: Cross-Tabulation of Teaching and Learning with Qualification

\begin{tabular}{|c|c|c|c|c|c|c|c|c|c|}
\hline $\mathbf{S N}$ & Item Question & Response & $\begin{array}{c}\text { BPharm } \\
(\%)\end{array}$ & $\begin{array}{c}\text { PharmD } \\
(\%)\end{array}$ & $\begin{array}{c}\text { MPharm } \\
(\%)\end{array}$ & Other & $\mathbf{X}^{2}$ & DF & $\begin{array}{c}P \text { - } \\
\text { value }\end{array}$ \\
\hline \multirow[t]{3}{*}{1} & \multirow{3}{*}{$\begin{array}{l}\text { Your curriculum enabled } \\
\text { you to think critically in } \\
\text { consideration of evidence } \\
\text { and to make decisions on } \\
\text { that basis }\end{array}$} & $\begin{array}{l}\text { Strongly } \\
\text { Agree }\end{array}$ & 73.9 & 17.4 & 8.7 & - & 5.540 & 6 & 0.477 \\
\hline & & Agree & 71.4 & 20.0 & 2.9 & 5.7 & & & \\
\hline & & Indifferent & 70.0 & 10.0 & 20.0 & - & & & \\
\hline \multirow[t]{3}{*}{2} & \multirow{3}{*}{$\begin{array}{l}\text { Your curriculum built } \\
\text { your capacity to develop } \\
\text { the knowledge and skills } \\
\text { to critically assess } \\
\text { scientific evidence }\end{array}$} & $\begin{array}{l}\text { Strongly } \\
\text { Agree }\end{array}$ & 59.1 & 31.8 & 9.1 & - & 18.569 & 6 & 0.005 \\
\hline & & Agree & 87.5 & 7.5 & 2.5 & 2.5 & & & \\
\hline & & Indifferent & 28.6 & 28.6 & 28.6 & 14.3 & & & \\
\hline \multirow[t]{3}{*}{3} & \multirow{3}{*}{$\begin{array}{l}\text { You were encouraged to } \\
\text { participate research and } \\
\text { scholarly activities to } \\
\text { generate new knowledge } \\
\text { in pharmacy }\end{array}$} & $\begin{array}{l}\text { Strongly } \\
\text { Agree }\end{array}$ & 65.5 & 24.1 & 6.9 & 3.4 & 7.153 & 6 & 0.307 \\
\hline & & Agree & 78.4 & 13.5 & 5.4 & 2.7 & & & \\
\hline & & Indifferent & 50.0 & - & 50.0 & - & & & \\
\hline
\end{tabular}

\section{Reliability of the Instrument}

The factor loading for all the items were between 0.601 to 0.869 and the Cronbach alpha value for the questionnaire was 0.961 . This shows that there was an internal consistency within the items. This therefore indicate that the questionnaire used for this study is valid and can also be used for subsequent studies of this form.

\section{DISCUSSION \\ Demography}

Majority of the respondents were between the age of 21 and 25, which suggest that many of the participants at the certification programme were at the early stages of their career. The female respondents were more than their male counterparts, and they accounted for more than half of the respondents. This is expected, as studies have reported that there are more females than males practicing in various areas of the pharmacy profession [24,25]. A higher number of the respondents obtained their pharmacy degree from Asian countries, suggesting that schools on that continent are most sought after by Nigerians that consider going abroad to study pharmacy. In this study, majority of the respondents had BPharm degree, suggesting that many foreign universities were yet to completely transit to the PharmD curriculum. Conceptually, Doctor of pharmacy programmes (PharmD) are expected to produce 
pharmaceutical care experts and provide more clinical experiences during training [26]. In the extant literature, some experts strongly advocate for adopting PharmD programme as an entry-level degree in developing countries, whilst others have indicated skepticism as regards its suitability for developing country needs $[27,28]$.

\section{Teaching and Learning}

In the findings of this study, majority of the respondents perceived that their curriculum had developed their capacity to improve the knowledge and skills to critically assess scientific evidence. Problem solving is one of the concepts central to the critical thinking approach [29]. The confidence of the respondents in this study corroborates findings from earlier studies. Problem solving ability and critical thinking have been identified as an important outcome in pharmacy education that underpins the ability of the professional to think logically and analytically when faced with practice-based challenges [30,31]. Without these skills, there is a risk that following graduation, pharmacists' confidence to practice may be severely limited to only the narrow professional areas related to the courses they studied while in university [32]. Many of the respondents also indicated that they were encouraged to participate in research and scholarly activities so as to generate new knowledge in pharmacy practice. The reason behind this, could be linked to the fact that majority of the respondents had Bachelor of Pharmacy degree unlike the Doctor of Pharmacy programme where the focus is more on pharmaceutical care [33]. For policymakers and regulators, this is an important finding that should guide the granular articulation of their reforms in pharmacy education. Whilst developing the roadmap for transiting to the PharmD programme, care must be taken not to lose the strong research component associated with the BPharm programme. This study also revealed for the first time, new knowledge associated with foreign trained pharmacists. There was a statistically significant correlation between continent of study and some of the respondents' views and experiences on teaching and learning. Respondents that studied Europe seemed less confident in their ability to think critically, compared to those who that studied in Asia. Since this is the first time that this finding is emerging in the literature, there is need for further research in this area to better explore the emergent relationships.

A considerable proportion of the sample were assessed using the conventional summative methods such as examinations. Whilst majority of the respondents were satisfied with this method of assessment a fifth of the respondents indicated a lack of satisfaction with this mode of assessment. This finding provides some insight into current assessment approaches, whilst also signposting areas for new reforms. Problem-based learning has since been
}

introduced into pharmacy curriculum of some universities as an adjunct to conventional didactic classroom model of teaching. This method of teaching was first developed at McMaster University in the 1960 s and it uses problems or cases to stimulate students to construct the most appropriate solution [3437]. There is evidence that adopting this approach in reforming pharmacy curricula can help inculcate problem solving, critical thinking, and self-directed learning into the skill-set that the pharmacists brings into their practice environment [38]. Findings from this study however suggests that many schools of pharmacy are not using this problem-based learning method as less than one-tenth of this study's respondents were assessed using critical thinking method. Furthermore, two-thirds of the respondents indicated that they preferred critical thinking feed-back method of assessment and evaluation, indicating the appetite for this innovative approach. Interestingly, although respondents indicated that they were not assessed using problem-based learning method, majority of them indicated that their curriculum built their capacity to think critically. Further insight is required to better understand the intricacies behind these complex relationships, and how best to leverage them to design contextual reforms. Considering problem-based learning approaches which lean heavily on cognitive science and pedagogy can no doubt stimulate curriculum reforms that allow students to apply critical thinking skills in solving problems. There is evidence in the literature that has demonstrated better utility of this approach for contemporary practice, compared to conventional learning [39]. Findings from this study can therefore begin to provide the contextual evidence to support similar reforms in our contextual setting.

\section{CONCLUSION}

The study revealed that the respondents were somewhat satisfied with the method of assessment associated with their training, but would have preferred the problem-based learning method due to its critical thinking component. Schools of pharmacy are therefore encouraged to consider adopting a curriculum underpinned by problem-based learning methodologies and critical thinking feedback mechanism to train and evaluate students, especially as these skills appear most appropriate for contemporary pharmacy practice. Policymakers and regulators of pharmacy education, particularly in developing countries considering reforms, are advised to infuse problem-based learning methodologies in their curricula, so as to improve the quality of pharmacy graduates produced in their relevant universities. In addition, the global transition from the BPharm curriculum to PharmD curriculum should be expedited to enable the emergence of a new cohort of pharmacists with pharmaceutical care expertise as well as critical thinking skills appropriate to healthcare issues in their various relevant settings. 
This study has provided a hitherto unknown insight into Nigerian students' inclinations when they consider studying pharmacy abroad. The findings from this study can help stakeholders design relevant policies, such as exchange programmes, course incentives and regulatory activities. It would however be interesting to undertake further research to uncover the drivers and facilitators for the preference to study pharmacy in Asian universities. These findings can consequently be considered in contextual reforms to improve the Nigerian system. Furthermore, a similar study should be undertaken amongst Nigerian trained pharmacy graduates as regards their views and experiences with the pharmacy curriculum in Nigeria.

\section{REFERENCES}

1. Fraser W, Killen R. Factors influencing academic success or failure of first-years and senior students: Do education students and lecturers perceive things differently? South African Journal of Education. 2003;23(4):254-260.

2. Amosun SL, Hartman N, Janse van Rensburg V, Duncan EM, Badenhorst E. Processes in widening access to undergraduate allied health sciences education in South Africa. African Journal of Health Professions Education. 2012;4(1):34-39.

3. Brown B, Skau K, Wall A. Learning across the curriculum: Connecting the pharmaceutical sciences to practice in the first professional year. Am J Pharm Educ. 2009;73(2):36

4. Trigwell K, Prosser M. Improving the quality of student learning: The influence of learning context and student approaches to learning on learning outcomes Higher Educ. 1991; 22(3): 251-266

5. Tynjälä P. Developing education students' conceptions of the learning process in different learning environments Learning Instruction. 1997; 7(3): 277-292

6. Tynjälä $\mathrm{P}$ Traditional studying for examination versus constructivist learning tasks: Do learning outcomes differ? Stud in Higher Educ. 1998; 23(2): 173-190

7. Antepohl W, Herzig S. Problem-based learning versus lecture-based learning in a course of basic pharmacology: a controlled, randomized study. Med Educ. 1999;33(2):106-113

8. Johnson JF, Bell E, Bottenberg M. A multiyear analysis of team-based learning in a pharmacotherapeutics course. Am J Pharm Educ. 2014;78(7):Article 142

9. Beleh M, Engels M, Garcia G. Integrating a new medicinal chemistry and pharmacology course sequence into the PharmD curriculum. Am J Pharm Educ. 2015;79(1):Article 13

10. Islam MA, Schweiger TA. Students' perception of an integrated approach of teaching entire sequence of medicinal chemistry, pharmacology, and pharmacotherapeutics courses in PharmD curriculum. J Pharm Pract. 2015;28(2):220-226.
11. King RG, Paget NS, Ingvarson LC. An interdisciplinary course unit in basic pharmacology and neuroscience. Med Educ. May 1993;27(3):229237

12. Marshall LL, Nykamp D. Active-learning assignments to integrate basic science and clinical course material. Am J Pharm Educ. 2010;74(7): Article 119.

13. Jones JS, Tincher L, Odeng-Otu E, Herdman M. An educational board game to assist PharmD students in learning autonomic nervous system pharmacology. Am J Pharm Educ. 2015;79(8): Article 114.

14. Brandl K, Schneid SD, Tsunoda SM, Awdishu L. Assessing Students' Satisfaction with a Redesigned Pharmacology Course Series. American Journal of Pharmaceutical Education September. 2019, 83(7): 6971

15. Karaksha A, Grant G, Anoopkumar-Dukie S, Nirthanan SN, Davey AK. Student engagement in pharmacology courses using online learning tools. Am J Pharm Educ. 2013;77(6):Article 12

16. Akpa SO, Adigwe OP. Medicines' Security: Consolidating Health Access Gains \& Catalysing National Development in the New Year. Business Day. 2018; Available at website https://businessday.ng/analysis/article/medicinessecurity-consolidating-health-access-gainscatalysing-national-development-new-year/amp/ (accessed $1^{\text {st }}$ May 2020).

17. Insull P, Blyth P. Basic science confidence in senior medical students from the University of Auckland, New Zealand: Results of the 2005 Senior Students Survey. $N \quad Z$ Med $J$. 2006;119(1247):23-64

18. Visconti CF. Problem-based learning: Teaching skills for evidence-based practice. Perspectives on Issues in Higher Education 2010;13(1):27-31.

19. Karimi R. Interface between problem-based learning and a learner-centered paradigm. Adv Med Educ Pract 2011;2:117-125.

20. Steck TR, DiBiase W, Wang C, Boukhtiarov A. The use of open-ended problem-based learning scenarios in an interdisciplinary biotechnology class: Evaluation of a problem-based learning course across three years. J Microbiol Biol Educ. 2012; 13(1):2-10.

21. Saira A, Mohammad AH, Ayesha I, Nyla J, Abida L, Naveed U, Shujaat AK, Yasmeen A, Ghulam M. A Qualitative Analysis of the Perception of Academic Pharmacists Regarding their Role in Healthcare System of Two Pakistani Cities. Tropical Journal of Pharmaceutical Research. 2015; 14(2): 311-315

22. Ilker E, Sulaiman AM, Alkassim RS. Comparison of Convenience Sampling and Purposive Sampling. American Journal of Theoretical and Applied Statistics. 2016;5(1): 1-4

23. Bryman A, Cramer D. Quantitative Data Analysis with SPSS for Windows. A Guide for Social 
Scientists. A Guide for Social Scientists. 2002;1849

24. Siracuse MV Schondelmeyer SW Hadsall RS Schommer JC Third-year pharmacy students' work experience and attitudes and perceptions of the pharmacy profession Am J Pharm Educ. 2008; 72(3) Article 50.

25. Selmi M, Weil S. Can all women be pharmacists? A critique of Hanna Rosin's The End of Men. Boston University Law Rev. 2013; 93:851-870.

26. Ahmed SI, Hassali MAA. The controversy of PharmD degree. Am J Pharm Educ. 2008;72(3): Article 71.

27. Anderson C, Futter B. PharmD or needs-based education: which comes first? Am J Pharm Educ. 2009;73(5): Article 92

28. Khan T, Anwar M, Ahmed KM. A perspective for clinical pharmacy curriculum development and validation in Asian developing nations. J Young Pharm. 2011;3(2):151-154

29. Facione PA. Critical Thinking: What it is and why it counts. Millbrae, CA Measured Reasons and the California Academic Press.2015; 1-30

30. Miller DR. An Assessment of critical thinking: Can pharmacy students evaluate clinical studies like experts? Am J Pharm Educ. 2004; 68 Article 5

31. Oderda GM, Zavod RM, Carter JT, Early JL, Joyner PU, Kirschenbaum K, Mack EJ, Traynor $\mathrm{AD}$, and Plaza CM. An Environmental Scan on the Status of Critical Thinking and Problem Solving Skills in Colleges/Schools of Pharmacy: Report of the 2009-2010 Academic Affairs Standing Committee. American Journal of Pharmaceutical Education. 2010; 74(10): S6.
32. Halpern DF. Teaching for critical thinking: Helping college students develop the skills and dispositions of a critical thinker. In New Directions for Teaching and Learning. 1999; (80): 69-74.

33. Amy M. Franks. Design and Evaluation of a Longitudinal Faculty Development Program to Advance Scholarly Writing Among Pharmacy Practice Faculty. American Journal of Pharmaceutical Education. 2018; 82(6): 6556

34. Prescott WA Jr.., Woodruff A, Prescott GM, Albanese N, Bernhardi C, Doloresco F. Introduction and assessment of a blended-learning model to teach patient assessment in a doctor of pharmacy program. Am J Pharm Educ. 2016; 80(10): Article 176.

35. Conway SE, Johnson JL, Ripley TL. Integration of team-based learning strategies into a cardiovascular module. Am J Pharm Educ. 2010;74(2):Article 35

36. Beatty SJ, Kelley KA, Metzger AH, Bellebaum KL, McAuley JW. Team-based learning in therapeutics workshop sessions. Am J Pharm Educ. 2009;73(6): Article 100

37. Franklin AS, Markowsky S, De Leo J, Normann S, Black E. Using team-based learning to teach a hybrid pharmacokinetics course online and in class. Am J Pharm Educ. 2016;80(10):Article 171

38. Cisneros RM, Salisbury-Glennon JD, AndersonHarper HM. Status of problem-based learning research in pharmacy education: a call for future research. Am J Pharm Educ. 2002; 66:19-26.

39. Mabope LA, Meyer JC. Access, pass, throughput and dropout rates: Review of a problem-based learning BPharm curriculum at a previously disadvantaged university in South Africa. October AJHPE. 2014; 6(2): 134-137. 